\title{
Phonotactic Parameters of Final Consonant Clusters in Iraqi Arabic and Kuwaiti Arabic: Some Contrastive Points
}

\author{
Majid Abdulatif Ibrahim \\ Dept of English and Translation, Faculty of Arts, Al-Zaytoonah Private University of Jordan, Jordan \\ Email: majidabd2@hotmail.com
}

\begin{abstract}
The present paper throws light on the field of phonotactics in which the treatment of final consonant clusters of Iraqi Arabic and Kuwaiti Arabic are investigated in order to trace the contrastive points of the two. It has been investigated that at the phonological level, differences are seen in phonological contrasts between forms purely on the basis of sound unit distributions. However, the contrasting features are not confirmed to one segment of the form, but, in some contexts, concern the syllabification of the whole form or part of it.
\end{abstract}

Index Terms-Iraqi Arabic, Kuwaiti Arabic, consonant clusters, anaptyctic vowels, syllabification, phonotactics

\section{INTRODUCTION}

Setting a comparison of the dialects of Arab Gulf with those of the outer Arab Peninsula, namely Kuwaiti Arabic and Iraqi one, reveals a marked generalization. However, it has been observed that the process of linguistic contrast produces a somewhat idiosyncratic phonological system. There are more features distinguishing some dialects from the various neighboring ones than there are distinguishing dialects from each other. Non-reductional as they are, these features may continue mergers of distinct items. Moreover, they can, in most cases, be characterized as analogical in nature, i.e. resulting from the phonological 'pressure' within the language or variety, and this, in turn, leads to a substantial increase in complexity.

At the phonological level, differences are seen in phonological contrasts between forms purely on the basis of sound unit distributions. Nevertheless, the contrasting features are not confirmed to one segment of the form, but, in some contexts, concern the syllabification of the whole form or part of it. It has been found that the statement of the clinal contrast of Iraqi Arabic and Kuwaiti one is facilitated by some sort of defining the phonological structures in terms of morphology. This is attributed to the fact that certain consonant clusters are possible with particular morphological structures.

The present treatise effort is based chiefly on the field of phonotactics in which the treatment of final consonant clusters of Iraqi Arabic and Kuwaiti Arabic are investigated in order to trace the contrastive points of the two. In attempt to meet the highest standards of objectivity and reliability, The study depends on recording the speech of informants of the two dialects. The recordings take the form of two phonemically transcribed texts with their full translation as illustrated in Appendix (1) and Appendix (2).

\section{Consonant Clusters: Phonotactic Generalizations}

Analyzing the syllable structure of any language is of prime importance as to how restrictions can be worked out on the possible combinations of sound segments. Such an analysis, no doubt, contributes to know the types of clusters that are utilized to pinpoint areas, say, of pronunciation problems.

Phonologically, the syllable is viewed as a unit of great value according to which the distributions or possibilities of sequential occurrence of phonemes are to be established (Robins, 1964, p. 139). The phonological description of languages generally includes a description of the phonemes and the positions they occupy. Giving a viewpoint of the "texture" of syllable, Abercrombie (1967, p. 38) assumes that segments of the syllables, which are sequential of the complex succession of movement, can be obtained by decomposing the syllable. These 4 segments fall naturally into two groups, i. e. vowels and consonants.

Central to the account of the possible consonant combinations, phonotactics arises as a general term referring to those permitted strings of phonemes including clusters, sequences, distributional restrictions and admissible syllable patterns (Lass, 1984, p. 21). It represents the way in which phonemes combine togetherin a particular language. By general agreement, it is pointed out that the permitted phoneme sequences are much restricted and only a number of combinations that can be formed by combining phonemes in all possible ways occur. These phono0tactic constraints vary considerably between languages in that it is possible to find languages with the same phonemes but diverge in the manner the phonemes are jointed together (McMahon, 2002, p. 55). Similarly, Carr (1993, p. 105) maintains that 
"certain rules include, not only feature-changing rules, but also rules expressing both language-specific and universal restrictions".

In their phonemic study of vowels and consonants, Cohen and McCarthy (1994, p. 52) reports that consonant phonemes can be arranged systematically on the account of the rules of distribution that govern their use. The rules are elicited by examining the actual occurrence of consonant phonemes in words. Besides, the distribution should include the relation that is drawn between a phoneme and the whole context where it occurs, and the 3 relation drawn between a phoneme and a following or a preceding phoneme or phonemes.

On the same footing, languages differ as to the types of the syllable structure that they admit. The difference is mainly a matter of the extent to which different languages permit consonant clusters to occur at the beginning or end of syllable. For example, many varieties of Modern Standard Arabic admit no initial consonant clusters at all, but allow final clusters of two or three consonants. In some occasions, not only the number of consonants occurring initially and finally in syllables is always subservient to constraints imposed by the phonological structure of the language, but the particular sequences of consonants occurring in clusters are also limited (Catford, 2002, p. 208).

Treating consonant clusters from a different angle, Pulgram (1970, p. 93) believes that the very use of cluster should be manipulated for monosyllabic and occurring group of consonants, whether coda or onset, while sequence is used for those groups of consonants that are dissolvable through syllabification into coda and onset consisting of two clusters, of two consonants or of cluster and consonant. Different terms such as "para-cluster" or "para-sequence" are adopted to stand for a consonantal group that occurs and must be therefore accounted for in a syllabic analysis but whose status is questionable. On closer inspection, Pulgram (ibid.) draws the line of demarcation between these two terms, committing

a group which does not occur word-medially as a cluster even though word-medially it would be termed as sequence or whose occurrence is marginal and uncertain in structure is a para-cluster; a para-sequence is therefore a group which, upon syllabification, delivers one or two para-clusters.

In addition to para-cluster and para-sequence, Plugram (ibid, p. 94) introduces further terms in dealing with consonant clusters and clustering in general. He points out that it is possible to use "quasi-cluster" and "quasi-sequence" to name groups that are structurally sounds, but do not occur as clusters or sequences, and in such a case, they cause structural, paradigmatic gaps. On the other hand, terms like "quasi-para-cluster" and "quasi-para-sequence" are also taken into account in relation to "groups that are both non-occurring and structurally non-sound, which means any group of consonant not fitting any of earlier classes" (ibid.).

Cruttenden (2007, p. 239) states that though plain, the general pattern of word-initial and word-final phoneme sequences poses certain problems. For instance, some sequences set word examples which are of rare occurrence. They are, strictly speaking, included in the statements of potential clusters. Others are either examples used in certain proper nouns or examples of recently imported foreign words. Moreover, the greater complexity of final consonant clusters is largely accounted for by the fact that some consonants frequently represent a suffixed morpheme. The statements of word-final clustering possibilities are not simplified by excluding suffixes. It is, however, simplified if suffixed consonants in question are treated as appendices or "extrametrical" to the basic syllable structure.

It has been observed that consonant clusters tend to have sound changes proceeding in the direction of "cluster reduction". The cluster reduction as such is usually determined by certain rules, i.e. when the consonant adjacent to the vowel on either side is an approximant, it is more likely to be elided than the outer consonant (Hawkins, 1992, p. 269). As for final consonant clusters, the reduction is greater in comparison with initial ones as might be expected from their post-peak position. The cluster reduction may also arise as a result of compounding. Here, since both initial and final clusters are permitted and above all compounding is favored as word formation process, "we can expect the formation of some rather dense clusters, which will be subjected to reduction" (ibid.).

\section{IRAQi ARABiC AND KuWAiti ARABic: Dialects of DEMOGRAPHiC VARIATIONS}

Dialectological attempts have been made to relate the distribution of linguistic variants in the spoken Arabic of Iraq and Kuwait to certain geographical areas on the one hand and to certain demographically isolated groups on the other.

As far as Iraqi Arabic is concerned, the geographical areas are related to communication patterns of pre-automobile times and to some extent group around the main waterways of the area: the Tigris, Euphrates and Shatt al-Arab. The demographic groupings particularly involve what may be referred to as a degree of standardization and also a degree of contact with the nomad populations in the desert to the west of the Euphrates. It is true that in some cases, the social and regional groupings are coextensive. However, the distribution between the two is drawn to tackle the linguistic features correlating with demographic relevance in other areas of Iraq (Ingham, 1997, p. 27).

Iraqi Arabic represents the speech of the groups referred to in the local taxonomy Sarab "nomadic population" and $\hbar a \underline{\partial a r}$ "sedentary population". Though the term ћaðar includes all urban population within Iraq and groups classed as

Sarab are in all cases rural, the two terms are not associated with urban/rural division. No universal criterion is set up for the usage of these terms throughout the area. It is, nevertheless, possible to sum up the main contrast which they imply. Haðar displays some sort of established settled population along rivers. The main towns of the area are situated within such areas whose population is also regarded as ћaðar by the rural inhabitants, though this system of 
classification is not used among the town-people. Sarab shows the less stable population of the interior away from the river banks, many of whom are nomadic or semi-nomadic (ibid.).

Distinct from what has been stated above, Field (1980, p. 252) remarks that in Iraq, there seems to be more than one usage. In one place, the contrast follows the pattern in which riverside palm cultivators are compared with the rest including both nomads and those of more recent sedentarization. In the second place, the term Sarab is retained exclusively for the nomad population and haðar for the sedentary. Out of the above classification system are two groups, both of whom are traditionally nomadic. The first is kwawla or kawliya, people akin to the gypsies of Europe. They speak Iraqi as their first language and retain only vestiges of their original Aryan tongue. The second group is mi'adaan "marsh Arabs" living in the marshlands of the Hoor al- Hammar and Hoor al Huwaiza occupied in buffalo breeding and the production of matting for sale (Salim, 1962, p. 9).

As for Kuwaiti Arabic, the picture is painted and framed differently. Recently a number of descriptions of Kuwaiti Arabic has appeared enlarging researchers' knowledge of an area which was little known previously. The main sources available are descriptions of émigré Imtairi and Dhafiiri tribes of Kuwait and Hafar al-Batin desert (Johnstone, 1967, p. 2). The general picture is that there are basically two sub-dialects spoken in Kuwait: Dhafiiri (or northern) and Imtairi (or southern). The former is spoken in the north of Kuwait, i.e. Al-Muttla'a, Al-Jahra'a and so on, while the latter in the Kuwait city, Al-Ahmedi, Al-Wafra...etc.

The account of Imtairi dialect is used as being the speech of the Eastern branch of Imtair, Alwat Imtair in comparison with that of the Western br5anch, i.e. Bani Abdullah. The tribal area extends from the borders of Al-Salmi in the west to the Gulf coast on the east of the city of Kuwait. Generally, Kuwaiti Arabic is fundamentally of Eastern Arabian dialectal group $^{(\mathbf{1})}$, and shows a strong affinity to Central Najdi type (Ingham, 1986, p. 23).

Dhafiir, though direct neighbours of Imtair, speak a sub-dialect of a quite different type, basically North Najdi, similar to the speech of the Shammar tribes, but with some amalgamation of Central Nadi features (Holes, 1990, p. 51). It seems that in this area, a dialect is a marker of tribal identity and since there is no gradation between membership of Dhafiir tribe and membership of Imtair one, these sub-dialects are similarly demarcated geographically. The boundary between Dhafiir and Imrair also constitutes a far-reaching boundary between Ahal al-Shamaal and Ahal al-Jinuub, i.e. northern and southern Bedouins.

\section{Phonotactic Treatment of Final Consonant Clusters}

A phonological feature of high incidence that separates Iraqi Arabic and Kuwaiti one is the treatment of underlying consonant clusters in word and stem final position. A marked difference is that in Iraqi Arabic, an anaptyctic vowel is inserted between the two consonants when in pause or a preceding consonant, while in Kuwaiti Arabic this takes place in a more restricted set of cases. Taking a generally applicable example, the contrast is as follows:

$\begin{array}{lcc}\text { Iraqi Arabic } & \frac{\text { Kuwaiti Arabic }}{1 . \int \text { ifit }} & \text { "I saw" } \\ \text { 2. } \int \text { ifitha } & \int \text { ift } & \text { "I saw her" } \\ \text { 3. } \int \text { iftah } & \int \text { iftaha } & \text { "I saw him" }\end{array}$

In forms (1) and (2), Iraqi variety shows a vowel /i/ between the two elements of the final cluster/-ft/. In form (3), this is not present as the cluster followed by the initial vocalic suffix /-ah/. In Kuwaiti Arabic, no such anaptyctic occurs though in form (2) a different type of anaptyctic occurs between the stem $/ \mathrm{S}$ ift-/ and the suffix /-ha/ warding off the junction of three consonants, which is not, in turn, permissible in certain contexts.

These contrasts occur with nominal forms of the pattern CaCC or CiCC, e.g. /galb/ "heart" and /bi $\mathrm{t} /$ "cloak", with verbal forms of the suffix /-t/: /riht/ "I went" and with a small number of imperatives of final weak verbs ${ }^{(2)}$ such as /im S / "go" or /iћt / " talk". In these three cases, the underlying form can be regarded as identical so that the contrast is one of surface derivational phonology as revealed by the total scatter of forms such as shown above. There are also some other structures involving the suffix /-k/ and /- $\mathrm{t} /$ where the Kuwaiti variety makes use of a final cluster, i.e. /ani $\int \mathrm{idk} /$ "I ask you (m.s)" and /ani $\int \mathrm{dt} /$ "I ask you (f.s)". Here, the forms do not have corresponding underlying structures in Iraqi Arabic where the suffixes are/-ak/ and /-itf/giving /ani $\int \mathrm{dak} /$ and /ani $\int \mathrm{dit} /$ /. However, the existence of the above various final cluster forms in Kuwaiti Arabic highlights a defining characteristic in contrast to Iraqi Arabic.

The contrast shown between the two dialects is of a clinal nature rather than a straightforward one between the presence and absence of final clusters. The clinality is attributed to some factors. In one place, an anaptyctic vowel does not occur in Kuwaiti Arabic associated with certain consonant cluster types. Relevant to this point are those anaptyctics associated with the liquid group, i.e. /l, n, r, ъ, m/. Secondly, in Iraqi Arabic, when the anaptyctic vowel occurs, it is extremely considered a full vowel on the ground of stress placement and syllabification. In Kuwaiti Arabic, it is not, nevertheless, counted as a full vowel for stress placement (see below).

In general, the nature of the transition from consonant to consonant in some consonant sequences distinguishes Kuwaiti Arabic from Iraqi Arabic. With voiced consonants, a definite vocalic transition of /ə/ is particularly heard in Kuwaiti Arabic which is absent in Iraqi one, for example:

$\underline{\text { Iraqi Arabic }}$

$\underline{\text { Kuwaiti Arabic }}$ 

hubatna
hubatəna
"we went down"
batni
batoni
"my stomach"

It clearly seems that Kuwaiti speakers do not perceive this as a vowel, but regard it as a feature of the release of the consonant. That the highly non-structural vocalic features exist in Kuwaiti Arabic makes the status of the final cluster anaptyctic of less structural importance in Iraqi Arabic.

The vocalic transition is heard with sequences of voiced consonants and also with the / $t$ / especially when the first consonant is a plosive or the second is $/ \mathrm{r} /$. The inclusion of $/ \mathrm{t} / \mathrm{is}$ shorter than for other voiceless plosives, and it may be that in many contexts, it is voiced. In Kuwaiti Arabic, the voiceless feature is not essential since it contrasts with / $\underline{\mathrm{s}} /$ and $/ \underline{\partial /}$. It is also relevant that the Arab phoneticians class $/ \underline{t} /$ as majhuur "sonorant", a class that includes voiced consonants ${ }^{(\overline{3})}$. Examples are given below from the speech of Kuwaiti speakers to elucidate the above case:
1. Satəni "give me"
2. natolaS "we come out"
3. ?igəðib "hold"

Bearing in mind the occurrence of the above type of vocalic transition in Kuwaiti Arabic, we can examine the stem final clusters in which differences of syllabification occur. In terms of their phonological behavior, they are of two major classes: those involving a liquid as the second element, and other types being different either in terms of stress assignment or in terms of syllabic structures in the majority of cases. As far as the first class is concerned, clusters that involve nominal forms $\mathrm{CaCC}$ or $\mathrm{CiCC}$ whose first element is not one of the guttural group $/ \mathrm{h}$, $\mathrm{x}$, and $\mathrm{R} /$, and whose second element is one of the liquids /m, l, r, n, and w/ show an anaptyctic /i/ or /u/ in both dialects:

$\begin{array}{ll}\text { Iraqi Arabic } & \text { Kuwaiti Arabic } \\ \text { kubur "size" } & \text { hadir "under" } \\ \text { Sur ul "work" } & \text { sabur "patience" } \\ \text { haðum "digestion" } & \text { hisin "beauty" } \\ \text { dihin "oil" } & \text { ragum "number" } \\ \text { gabul "before" } & \text { gabil "before" } \\ \text { mi } \theta \text { il "like" } & \text { badir "full moon" } \\ \text { wazin "weight" } & \text { baduw "bedouins" }\end{array}$

With a following initial vowel suffix or before a vocalic initial word, both varieties have elision of the anaptyctic vowel as in (a) below. In Kuwaiti Arabic, as the number of these forms contains combination of voiced consonant, the vocalic transition is often heard. However, this is absent in Iraqi Arabic giving contrasting sets of the type as in (b):

Iraqi Arabic
(a) $\operatorname{mi} \theta$ il

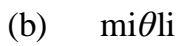

$\operatorname{mi} \theta$ il "like"
$\operatorname{mi} \theta$ əli "like me"

Kuwaiti Arabic

Equally important, with a following consonant suffix, both dialects generally retain the anaptyctic vowel. Nevertheless, while the vowel in Iraqi Arabic is considered a full vowel for stress assignment, in Kuwaiti Arabic, it is disregarded for this purpose:

\begin{tabular}{|c|c|c|}
\hline$\frac{\text { Iraqi Arabic }}{\operatorname{in}^{1} a i \operatorname{mum}}$ & $\frac{\text { Kuwaiti Arabic }}{\text { Imiailism }}$ & “6 \\
\hline wa'zinha & 'wazinha & "its weight" \\
\hline ga'bulha & 'gabulha & "before it" \\
\hline
\end{tabular}

In some cases, Kuwaiti forms act like the non-anaptyctic ones in this structure giving forms of such a type as /mi $\theta$ ləhum/ or /mi $\theta$ ələhum/. Moreover, with the final /j/ and /w/ especially Kuwaiti Arabic shows the non-anaptyctic forms occasionally: badwəna "our bedouins"

hatfjəkum "your talk"

Apart from the first class, the second one indicates that in Kuwaiti Arabic, no anaptyctic vowel, as a rule, occurs although there are contexts in which a sporadic vocalic transition occurs of the type described above. Iraqi Arabic, on the other hand, reveals that the anaptyctic /i/ or /u/ always occurs:

\begin{tabular}{lcl} 
Iraqi Arabic & Kuwaiti Arabic & \\
\cline { 2 - 2 } & SiS b & "grass" \\
wakit & wagt & "time" \\
zibid & zibd & "butter" \\
barug & barg & "light"
\end{tabular}

With the vocalic beginning suffixes, both dialects adopt elision of the anaptyctic providing such forms as /darbah, /darbih/ "his road". With the consonantal beginning suffixes, the anaptyctic in Iraqi Arabic is maintained, and as in the first class, it counts for stress in the extreme Iraqi type. Furthermore, In Kuwaiti Arabic, there are two possible structures, one with a further anaptyctic vowel separating the stem and the suffix, and the other with a tri-consonantal 
cluster. Examples of the first category are such forms as / iftahum/ "I saw them", /wagtukum/ "your time", /nafsaha/ "herself", whereas those of the second category are as follows: / $\mathrm{ifthum/} \mathrm{"I} \mathrm{saw} \mathrm{them",} \mathrm{/Rista} \int$ artni/ "she asked me my advice", /milkhum/ "their possession".

\section{CONCLUSION}

The different treatment of stem final clusters and the associated function of stem and affix can be considered one of the clearest and most generally recognized variables separating Iraqi speech and the Kuwaiti one. Kuwaiti speakers, when presented with forms spoken with the anaptyctic, usually recognize them as Iraqi, while Iraqis regard the nonanaptyctic forms as Kuwaiti or sometimes Bedouin. The vocalic transition between stem and suffixes is widely perceived as a dialect marker and speakers feel that the difference is of prime importance. Forms with the anaptyctic element are nearly used by all Iraqis including nomadic shepherd tribes. In Kuwaiti Arabic, no examples of anaptyctic clusters are found, though some Kuwaitis of Shammari origins may speak forms of interrogatives. This will be left to a coming study with new views, however.

\section{Notes}

(1) Socio-linguistically speaking, Kuwaiti Arabic and Zubairi Arabic show some sort of a considerable resemblance, since both of them descend from the same dialectal group, i.e. the Eastern Arabian dialectal group. For a fuller account on this point, see Ibrahim (2006).

(2) In Kuwaiti Arabic and most of other Gulf dialects, the morphology of verbal classes adopts a division into classes depending on the identity of the consonants occurring in the root. This involves basically a division into strong and weak roots. A weak root is a root which contains one of the consonants $/ \mathrm{j} /, / \mathrm{w} /$ or $/ \mathrm{R} /$ and in which these consonants have zero exponents. The property of "weakness" here is one of the particular stem type rather than of the root or of the consonant itself.

(3) See El-Sa'aran (1951).

Phonemic Symbols (After Johnstone, 1967)

\section{The vowels}

$\mathrm{i}$ as in Pibin "son"

$\overline{1}$ as in bir "well"

$\overline{\mathrm{e}}$ as in wēn "where"

a as in matbax "kitchen"

$\overline{\mathrm{a}}$ as in wāsta "means"

$\overline{\mathrm{o}}$ as in jōm "day"

u as in giltu "you said"

$\overline{\mathrm{u}}$ as in hdūm "clothes"

\section{The consonants}

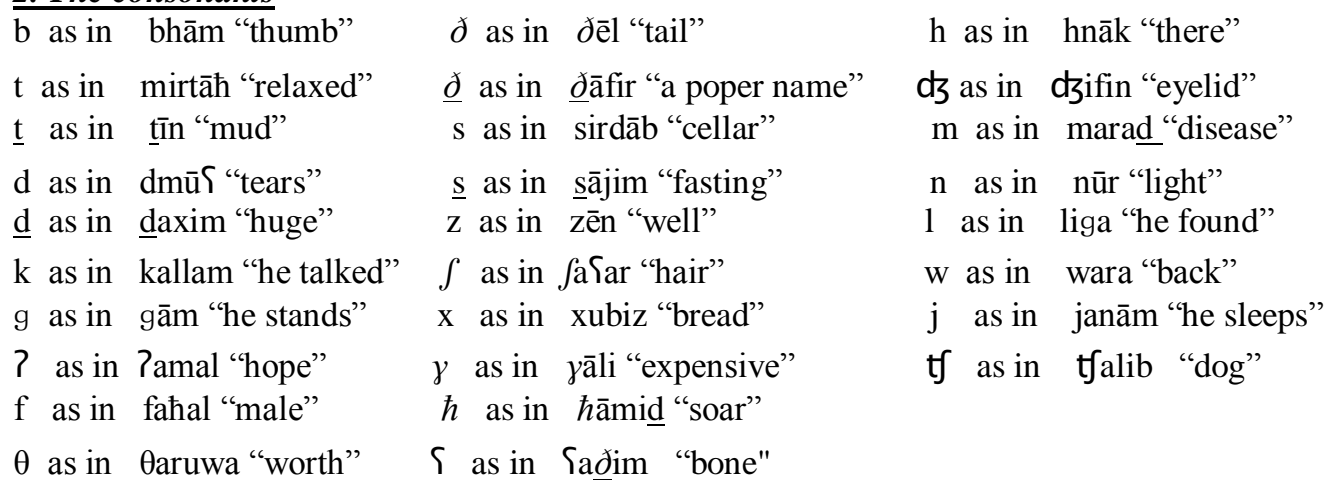

\section{APPENDIX (1)}

The text represents a folk story narrated by an old Iraqi man. The story is an example of a fairly widespread type of narrative containing references to various legendary figures.

\section{$\underline{\text { Text }}$}

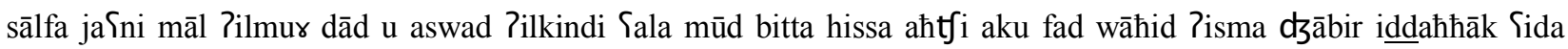

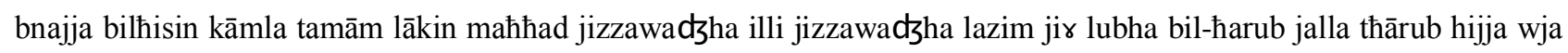

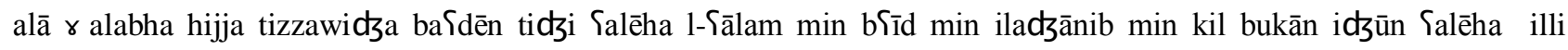

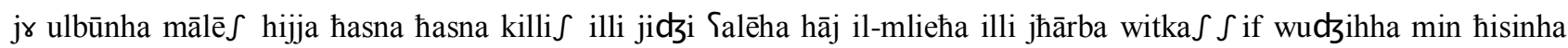

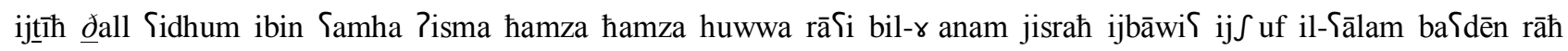




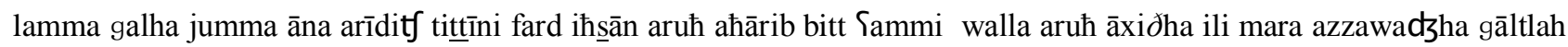
jumma inta wēnak u wēnha hāj idr ulbak witturhak witkitlak galilha lā inti mā Slēt āna ar lubha.

\section{Translation}

A story, I mean of Mughdad Al-Kindi about his daughter. Do I speak now? There was someone called Jabir AlDhahhak who had a beautiful daughter, perfect in beauty. But, nobody could marry her. Only the one, who could defeat her in battle, could marry her. If he fought her and if he beat her, then she could marry him. A great number of people came from afar, from other nations, from everywhere. They came for her, those who sought to defeat her why? The reason is that she was very beautiful. Whoever faced her, this beautiful one and wished to fight her. She just uncovered her face and he would fall unconscious from her beauty. She would come in and conquer him. There remained only her cousin whose name was Hamza. Hamza was a shepherd working with the sheep. He watched and saw all this multitude of people. Then, he went to his mother and said: "Mom, I want you to give me a horse so that I can fight my cousin and I will take her and marry her." His mother replied: "Who are you to think of your cousin? She will overcome you and throw you down and kill you." He said to her: "No, do not concern. I will beat her."

\section{APPENDiX (2)}

The text is a conversation between Kuwaiti speakers. They were students of Kuwait University and enacted this speech at break time in the university cafeteria.

$\underline{\text { Text }}$

A: sabbahk alla bal-xēr

B: jā hala sabāh al-xēr $\int$ lōnik

A: alla jsallimk

B: Yasāk tajjib kēf hālik

A: walla bxēr ahamdillāh jā walad marrēt Salēkum hāssbūS illi tāf bass mā ligētkum

B: jōm al-xamīs îh talâna lil-bar

A: mā $\int$ alla u $\int$ lōna al-dław ihnāk

B: walla zēn māhi mi $\theta$ il al- ām

A: ㄲh walla hi bass wanasatha walla tiswa

B: walla stānasna bil-barr hnāk Sind harraba؟

\section{Translation}

A: Good morning

B: Welcome Good morning to you. How are you?

A: God keep you

B: I hope you are well.

A: Praise be to God. I came to see you last week, but did not find you at home.

B: On Thursday. Yes. We went out to the desert.

A: Wonderful. How was the weather there?

B: It was perfect, but it was not like last year.

A: Yes, by God, it is just that the outing there is worthwhile.

B: Well, we enjoyed ourselves there in the desert among friends.

\section{REFERENCES}

[1] Abercrombie, D. (1967). Elements of General Phonetics. Edinburgh: Edinburgh University Press.

[2] Carr, Phillip. (1993). Phonology. London: Macmillan.

[3] Catford, J. C. (2002). A Practical Introduction to Phonetics. Oxford: Oxford University Press.

[4] Cohn, A. and McCarthy, J. (1994). Alignment and Parallelism in Indonesian Phonology. Massachusetts: University of Massachusetts.

[5] Cruttenden, A. (2007). Gimson's Pronunciation of English. London: Edward Arnold.

[6] El-Sa'aran, M. H. A. (1951). A Critical Study of the Phonetic Observation of the Arab Grammarians. Unpublished Ph. D dissertation. London: University of London.

[7] Field, H. (1980). Anthropology of Iraq. Chicago: University of Chicago.

[8] Hawkins, P. (1992). Introducing Phonology. London: Routlege.

[9] Holes, C. D. (1990). Gulf Arabic. London: Routlege.

[10] Ibrahim, Majid, Abdulatif. (2006). Syllable Structure and Syllabification in Zubairi Arabic: A Phonological Study from a CV Perspective. Unpublished Ph.D. dissertation. Basrah: University of Basrah.

[11] Ingham, B. (1986). Bedouin of Northern Arabia: Tradition of Al Dhafir. London: KPI

[12] Ingham, B. (1997). Arabian Diversions: Studies on the Dialects of Arabia. Reading: Ithaca Press.

[13] Johnstone, T. M. J. (1967). Eastern Arabian Dialect Studies. Oxford: Oxford University Press.

[14] Lass, R. (1984). Phonology. Cambridge: Cambridge University Press. 
[15] McMahon, A. (2002). An Introduction to English Phonology. Oxford: Oxford University Press.

[16] Pulgram, E. (1970). Syllable, Word, Nexus, Cursus. The Hague: Mouton.

[17] Robins, H. R. (1964). General Linguistics: An Introduction Survey. London: Longman.

[18] Salim, S. M. (1962). Marsh Dwellers of the Euphrates Delta. London: KPI.

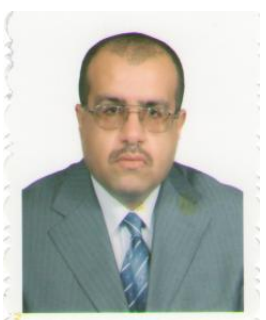

Majid Abdulatif Ibrahim was born in Zubair, Basrah, Iraq in 1970. He received his Bachelor's degree in English and English Literature from University of Basrah, Iraq in 1992, a master's degree in Applied linguistics/Phonetics and Phonology in 1994 , and his Ph. D. in General Linguistics/ Phonetics and Phonology in 2006.

He was a member of the Department of English, University of Shatt-el-Arab from 1997 until 1999. From 1999 to 2009 he served as a teaching staff member of the Faculty of Arts, University of Basrah, where he became an Assistant Professor of Phonetics and Phonology. When leaving Iraq, he served as an Assistant Professor of Linguistics and Phonetics at the Faculty of Arts, Al-Isra Private University of Jordan from 2009 until 2011. Then, he has been working as Assistant Professor of Linguistics and Phonetics at the Faculty of Arts, Al-Zaytoonah Private University of Jordan since 2011. His current areas of interest are Phonetics, Phonology, Syntax, Phonology of Iraqi and Gulf dialects. Dr. Ibrahim resides in Amman, Jordan, with his wife and their two children. 